\title{
Güncel Kılavuz Önerileriyle İnflamatuar Barsak Hastalıklarında Semptom Yönetimi
}

\author{
Berna Nilgün ÖZGÜRSOY URAN \\ İzmir Kâtip Çelebi Üniversitesi Sağlık Bilimleri Fakültesi, İzmir.
}

\begin{abstract}
ÖZET
İnflamatuar barsak hastalığı (IBH); Ülseratif kolit ve Crohn hastalığını içeren, idiopatik, kronik, relaps (alevlenme) ve remisyon (iyileşme) dönemleriyle seyreden intestinal mukozanın kontrolsüz inflamasyonudur. Kronik hastalık olması, remisyon sürecine girmenin zor ve uzun süreli olması, önemli sağlık bakım kaynakları gerektirmesi gibi nedenlerle İBH yönetiminde en etkili yöntem hastanın semptomlarına odaklanmak ve bu semptomları iyileştirmeye yönelmektir. Bu kapsamda hastaların tedavi yönetimindeki amaç da endoskopik iyileşmeyle birlikte semptomatik remisyonu sağlamaktır. İnflamatuar barsak hastalıklarında görülen semptomlar hastalığın aktivitesine ve lokalizasyonuna göre değişkenlik göstermektedir. Her iki hastalıkta da görülen majör semptomlar benzerlik gösterse de, İBH şiddetine göre hastanın deneyimlediği semptomların şiddeti farklı olmaktadır. Bu derlemede amaç; İBH semptomlarının seyrine, bu semptomların bütüncül olarak değerlendirilmesine ve iyileştirilmesine yönelik bilgilerin aktarılmasıdır. Bunun yanı sıra, semptomların hastaların yaşam kalitelerini nasıl etkilediğine, hemșirelerin hasta eğitiminde nelere değinmesi gerektiğine ve etkili bir semptom yönetimi sayesinde hastalığın remisyonda kaldığı sürenin uzatılmasına dair hemşirelik girişimlerine değinilmektedir.
\end{abstract}

Anahtar Kelimeler: İBH. Ülseratif kolit. Crohn hastalığı. Semptom yönetimi. Hemşirelik.

Symptom Management of Inflammatory Bowel Diseases with Current Guideline Suggestions

\begin{abstract}
Inflammatory bowel disease (IBD) which includes ulcerative colitis and Crohn's disease is an uncontrolled inflammation of the intestinal mucosa, with idiopathic, chronic, relapse and remission periods. The most effective method for the management of IBD is to focus on the patient's symptoms and to try to improve these symptoms because of chronic illness, difficult and long-term remission process, requiring important health care resources.In this context, the aim of treatment management of patients is to provide symptomatic remission with endoscopic recovery.Symptoms seen in inflammatory bowel diseases vary according to the activity and localization of the disease. Although major symptoms were similar in both diseases, the severity of the symptoms experienced by the patient was different than the severity of IBD. The aim of this review is to provide information about the course of IBD symptoms, their holistic evaluation and improvement. In addition, nursing interventions about how symptoms affect patients' quality of life, what nurses should address in patient education and prolonging the remission of the disease through effective symptom management are described.
\end{abstract}

Key Words: IBD. Ulcerative colitis. Crohn's disease. Symptom management. Nursing.

İnflamatuar barsak hastalı̆̆ (İBH); Ülseratif kolit (ÜK) ve Crohn hastalığını (CH) içeren, idiopatik, kronik, relaps (alevlenme) ve remisyon (iyileşme) dönemleri ile seyreden intestinal mukozanın kontrolsüz inflamasyonudur. İnflamatuar yanit ve tutulum hastalık tipine göre farklılık göstermektedir. Ülseratif kolitteki inflamatuar yanıt mukoza ve submukozaya

Geliş Tarihi: 10.Aralık.2019

Kabul Tarihi: 03.Mart.2020

Dr. Berna Nilgün ÖZGÜRSOY URAN

İzmir Kâtip Çelebi Üniversitesi Sağlık Bilimleri Fakültesi

Merkezi Ofisler I. Çiğli, İzmir, Türkiye.

Tel.: 05445748771

E-posta: bernanilgun@gmail.com sınırlı iken; CH'deki inflamasyon, mukozadan serozaya kadar tüm duvar boyunca yayılım göstermektedir. Crohn hastalığı en sik olarak distal ince barsak ve kolonu tutmasına karşın, ağızdan anüse kadar gastrointestinal kanalın herhangi bir yerinde segmenter tarzda görülebilir. Ülseratif kolitteki inflamasyon ise genellikle kolon ile sınırlı olmakla birlikte arada sağlam segment bırakmaksızın diffüz yüzeyel tutulum göstermektedir ${ }^{1-4}$.

Ülseratif kolit ve $\mathrm{CH}$ çok çeşitli semptomlar ile ortaya çıkabilmektedir. Bu hastalıkların başlıca ortak özellikleri; relaps/remisyon dönemleriyle klinik seyir göstermesi ve intestinal/ekstraintestinal belirtilerdir. Çoğu semptom hastalık aktivitesi ile ilişkili olmakla birlikte, bazı hastalarda ilaçların yan etkileri veya immünsupresyon nedeniyle de semptomlar gelişebilir. Bu gibi 
durumlarda, semptomları tetikleyen ilaçlar semptomların azalmasına kadar kesilebilir veya başka tedavi gereksinimlerini ortaya çıkarabilir. Etiyolojiden bağımsız olarak, yapılan değerlendirme ve uygun tedaviyle ortaya çıkan bu semptomlar hızla ele alınmazsa; bazı semptomlar kalıcı sekellere neden olabilirr ${ }^{2-4}$.

Mesalaminler, kortikosteroidler, immünmodülatörler ve biyolojik ilaçlar gibi birçok ajan İBH tedavisinde kullanılmaktadır. Tedavide amaç; endoskopik iyileşmeyle birlikte semptomatik remisyonu sağlamaktır. İdame tedavisi uygulanan remisyondaki hastalarda dahi öngörülemeyen nüksler görülebilmektedir. Ancak tedavide kullanılan ilaçlar, hastanın günlük aktivitelerini etkileyecek şiddette intestinal veya ekstraintestinal semptomlara neden olabilmektedir ${ }^{2,4-6}$. Kronik hastalık olmas1, remisyon sürecine girmenin zor ve uzun zaman alması, önemli sağlı bakım kaynakları gerektirmesi gibi nedenlerle İBH tedavisinde en etkili yöntem hastanın semptomlarına odaklanmak ve bu semptomları iyileştirmeye yönelmektir.

Bireyin biyopsikososyal, duygudurum veya bilișsel işlevselliğindeki değişiklikleri yansıtan “öznel” bir deneyim olan Semptom "işaret” veya"anormallik belirtisi” olarak da tanımlanmaktadır ${ }^{7}$. Belirtiler ve semptomlar, hastalık durumunu değerlendirmek, hastalık yönetim stratejilerinin etkinliğini değerlendirmek ve doğrulamak için hastaların ve klinisyenlerin dikkatini çeken önemli ipuçlarıdır. Bu nedenle hastalıkların tıbbi yönetiminde hastalara, asıl tıbbi durumla ve altta yatan nedenle ilişkisi olan semptomlar ve bu semptomların önemi öğretilmeli, hastaların farkındalıkları arttırılmalıdır $^{8}$. Bu derlemede amaç; İBH semptomlarının seyrine, bu semptomların bütüncül olarak değerlendirilmesine ve iyileştirilmesine yönelik bilgilerin aktarılmasıdır. Bunun yanı sıra, semptomların hastaların yaşam kalitelerini nasıl etkilediğine, hemşirelerin hasta eğitiminde nelere değinmesi gerektiğine ve hastalığın remisyonda kalma süresinin uzatılmasını sağlayabilecek etkili bir semptom yönetimine yönelik hemşirelik girişimlerine değinilmektedir.

\section{İnflamatuar Barsak Hastalıklarında Sık Görülen Semptomlar ve Semptom Yönetimi}

İBH belirtileri intestinal (barsak kaynaklı) olabildiği gibi, ekstraintestinal (barsak dışı) bir belirti olarak veya eşlik eden otoimmün bozukluklar nedeniyle de görülebilir. İnflamatuar barsak hastalıklarında görülen semptomlar hastalığın aktivitesine ve lokalizasyonuna göre değişkenlik göstermektedir. Her iki hastalıkta da görülen majör semptomlar benzerlik gösterse de, İBH şiddetine göre hastanın deneyimlediği semptomların şiddeti farklı olmaktadır. Diyare, ateş, aşırı yorgunluk, abdominal ağrı ve kramp, dışkıda kan görülmesi, tenesmus, iştah ve kilo kayıpları gibi intestinal semptomların yanı sıra diğer tüm sistemleri etkileyebilecek ekstraintestinal semptomlar her hastada farklı şiddette ortaya çıkabilmektedir $^{9-13}$.
Her hastanın her semptoma verdiği yanıt farklı düzeylerde olmaktadır, bu nedenle öncelikle hastanın semptomlarının varlığı, hastayı etkileme şiddeti değerlendirilerek her hastanın duruma göre bireyselleştirilmiş bir semptom yönetim planı oluşturulması gerekmektedir.

Semptom yönetimi; ciddi veya yaşamı tehdit edici hastalığı olan hastalarda tedaviye bağlı yan etkileri ve hastalığa ya da tedaviye ilişkin psikolojik, sosyal ve ruhsal sorunları önlemeyi amaçlayan bir yaklaşımdır ${ }^{14}$.

Herhangi bir semptomun veya semptom grubunun etkin olarak yönetimi, modelde yer alan üç boyutun da dikkate alınmasını gerektirir: Kişi alanı, Çevre alanı, Sağlık - Hastalık alanı. Semptom yönetim modeli aşağıdaki beş varsayıma dayanmaktadır (Şekil 1) ${ }^{8}$ :

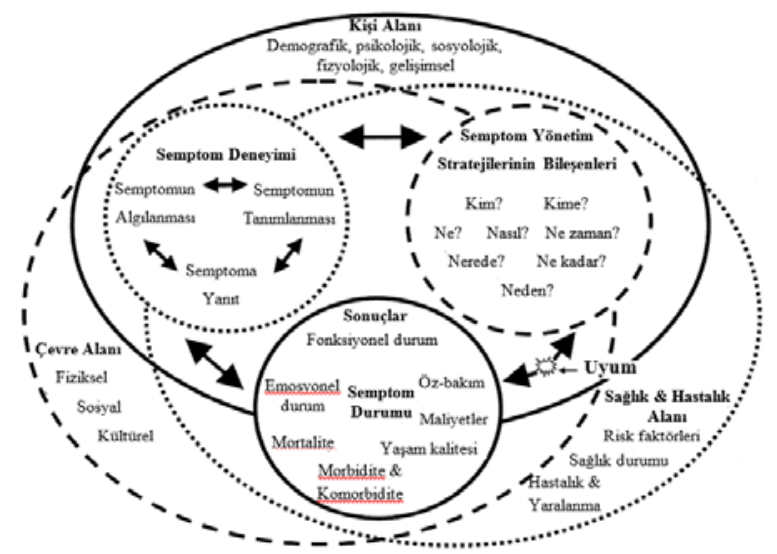

Şekil 1:

Semptom Yönetimi Modelinin Kavramsal Yapısı

- Semptomların araştırılmasında kullanılan altın standart; semptomu yaşayan bireyin algısı ve kendi ifadesidir.

- Semptom yönetimi modelini uygulamak için bireyin bu semptomu yaşaması gerekmez. Herhangi bir sebeple (meslek, genetik, aile öyküsü vb) birey, semptomun gelişimi açısından risk altında olabilir. Girişimlere yönelik stratejiler, birey semptomu yaşamadan önce başlatılabilir ve bu sayede semptom ortaya çıkmadan önlenebilir.

- Sözel ifade yetisi olmayan hastaların da (bebekler, inme sonrası afazik veya engelli bireyler, vb.) semptomları olabileceği ve ebeveynlerinin veya bakım verenlerinin ifadeleriyle semptomun tanımlanabileceği unutulmamalıdır.

- $\mathrm{Bu}$ yönetim stratejisi, bireyi, içinde bulunduğu toplumu, aileyi veya çalışma ortamını hedef alabilmektedir.

- Semptom yönetimini dinamik bir süreç olup, bireysel sonuçlara ve bireyin kişisel, sağlık / hastalık veya çevresel alanlarının etkilerine göre değişkenlik göstermektedir.

Hemşirelik uygulamalarında önemi giderek artan ve odak konulardan biri olan semptom yönetimi; hastaların semptomlarını hafifletmek, iyileştirmek ve yaşam 


\section{İBH ve Semptom Yönetimi}

kalitesini geliştirmek için daha iyi sonuçlara ulaşmayı sağlayabilir. Semptom yönetimi; hastanın yaşadığ sıkıntılara odaklanmayı kolaylaştırmakta, hangi semptoma öncelik verileceğini ve semptomun fizyopatolojik mekanizmasını bilerek bakım yaklaşımı geliştirmeyi sağlamaktadır ${ }^{4,8,15}$.

Bir semptomu belirlemenin en doğru yolu "bireyin semptomu kendisinin bildirmesi" ve "sözlü olarak ifade etmese de semptomu deneyimlemesi”dir. Hemşire; dinamik, değişken ve tekrar düzelebilen bu semptom yönetim sürecinde nitelikli ve uygun bakımı vermekten sorumludur. Bu sorumluluklar hastayı ve hastalığ 1 çok iyi tanımasını, hasta ile yakın bir iletişim halinde olmasını, hastanın gereksinimlerine göre bireyselleştirilmiş bir bakım yönetimini planlamasını gerektirmektedir.

İnflamatuar barsak hastalıklarında sık görülen semptomlar Tablo I'de intestinal ve ekstraintestinal olarak gruplandırılmıştır ${ }^{4-6,10,12,13,16-27}$. Gastrointestinal sistemi ve diğer sistemleri etkileyen tüm İBH semptomları; hastaların biyo-psiko-sosyal fonksiyonlarını etkileyebilen, zamana, hastalık aktivitelerine ve tedavi şekillerine göre değişiklik gösterebilen, çok boyutlu ve oldukça kompleks tablolardır. Tablo I’de gösterilen semptomlardan en sık görülenleri kanıt temelli olarak güncel kılavuzlar eşliğinde farmakolojik ve nonfarmakolojik yaklaşımlarla aşağıda kısaca açıklanmaktadır 3 ,4,10,12,13,23-25,28-33:

\section{IBH'de İntestinal Semptomlar}

Diyare: Hastalık aktivitesinin şiddetlendiği durumlarda kanlı, mukuslu ve sulu dışkılama görülür. Aktif ÜK kanaması, dışkıda gözle görülür kan ile birliktedir. Noktürnal diyare şeklinde görülebilir ve inkontinans eşlik edebilir. Rektal kanama ile birlikte görülen diyare temel beslenme ögelerinin, vücut sıvılarının ve elektrolitlerin kaybına neden olabilmektedir. Yemeklerden sonra daha sık görülür ${ }^{3,4,6,12,13,29,30,33}$.

Ülseratif kolitte, hastalığın başlangıcında ve aktivitenin az olduğu durumda da diyare vardır. Genellikle mukuslu feçes çıkartılmaktadır. İnaktif evrede diyare spastik kolon belirtisidir. Rektum tutulduğunda kanama, rektal kanama şeklindedir. Anal bölgenin tutulmas1 ile inkontinans belirmekte ve tenezm şiddetlenmektedir. Lezyon proksimale doğru yayıldıkça, önce üzerine kan bulaşmış feçes, daha sonra kanla karışık feçes çıkartılmaktadır. Crohn hastalığında ise diyare her zaman var olan bir belirtidir. Nedeni tam olarak bilinmese de, bakteri aşırı çoğalmasına, safra asidine ve uzun bir ileum segmentinin tutulumuna veya cerrahi olarak rezeke edilmesine bağlı olarak ortaya çıkabi$\operatorname{lir}^{5,10,12,13,23-25}$.
Tablo I. İBH türüne göre intestinal ve ekstraintestinal semptomlar

\begin{tabular}{|c|c|c|}
\hline Semptomlar & Ülseratif Kolit & Crohn Hastalığı \\
\hline \multicolumn{3}{|l|}{ Intestinal Semptomlar } \\
\hline Diyare & \begin{tabular}{|l|} 
Başlangıçta, aktivitenin \\
az olduğu durumlarda \\
görülür. Anal bölge \\
tutulumu olanlarda \\
inkontinans düzeyindedir
\end{tabular} & Her zaman \\
\hline Abdominal ağrı ve kramp & $\begin{array}{l}\text { Alt kadranda sık ve } \\
\text { şiddetli }\end{array}$ & Sık \\
\hline Dışkıda kan & $\begin{array}{l}\text { Karakteristik bulgu } \\
\text { Makro düzeyde } \\
\text { Rektal tutulumu olanlar- } \\
\text { da }\end{array}$ & \begin{tabular}{|l} 
Nadir \\
Mikroskobik \\
Kolon lezyonları \\
hâkim olanlarda \\
\end{tabular} \\
\hline $\begin{array}{l}\text { Acil defekasyon isteği (te- } \\
\text { nesmus) }\end{array}$ & $\begin{array}{l}\text { Sık } \\
\text { Rektal tutulumu olanlar- } \\
\text { da }\end{array}$ & $\begin{array}{l}\text { Nadir } \\
\text { Proktit varlığında }\end{array}$ \\
\hline İştah ve kilo kaybı & Hafif & Belirgin \\
\hline \multicolumn{3}{|c|}{ Ekstraintestinal Semptomlar } \\
\hline Bulantı ve Kusma & Sık & $\begin{array}{l}\text { Çok sık } \\
\text { Cerrahi için ön bulgu }\end{array}$ \\
\hline Ateş & Şiddetli vakalarda & $\begin{array}{l}\text { Düşük seyredebilir } \\
\text { Komplikasyonlar } \\
\text { gelişirse yükselir }\end{array}$ \\
\hline Halsizlik / Yorgunluk & Hafif & Orta \\
\hline Gece terlemesi & Şiddetli vakalarda & $\begin{array}{l}\text { Ateş yükselirse } \\
\text { görülür }\end{array}$ \\
\hline Anemi & Ağır şiddetli vakalarda & + \\
\hline $\begin{array}{l}\text { Artralij ve Artropati } \\
\text { - } \\
\text { - }\end{array}$ & $\begin{array}{l}\text { Sık } \\
\text { Sık } \\
\text { Sık } \\
\text { Sık }\end{array}$ & $\begin{array}{l}\text { Sık } \\
\text { Sık } \\
\text { Sık } \\
\text { Sık }\end{array}$ \\
\hline Metabolik kemik hastalığı & Nadir & Sık \\
\hline $\begin{array}{l}\text { Göze ilişkin bozukluklar } \\
\text { (episklerit, uveit) }\end{array}$ & Sık & Sık \\
\hline Oral ve nazal hastalıklar & Nadir & Sık \\
\hline $\begin{array}{l}\text { Deri hastalıkları } \\
\text { - Eritema nodosum } \\
\text { - } \text { Pyoderma gangrenosum }\end{array}$ & $\begin{array}{l}\text { Nadir } \\
\text { Nadir }\end{array}$ & $\begin{array}{l}\text { Sik } \\
\text { Nadir }\end{array}$ \\
\hline $\begin{array}{l}\text { Hepato-pankreato-biliyer } \\
\text { hastalık (Primer sklerozan } \\
\text { kolanjitis - PSK) }\end{array}$ & Sık & Nadir \\
\hline $\begin{array}{l}\text { PSK dışındaki karaciğer } \\
\text { hastalıkları (non-alkolik yağlı } \\
\text { karaciğer, ilaç kaynaklı } \\
\text { karaciğer hasarı, portal ven } \\
\text { trombozu, granülomatoz } \\
\text { hepatit) }\end{array}$ & Daha sık & Sık \\
\hline Akut pankreatit & Nadir & Nadir \\
\hline Kronik pankreatit & Daha sık & Sık \\
\hline $\begin{array}{l}\text { Nörolojik hastalıklar (Periferal } \\
\text { nöropati) }\end{array}$ & Nadir & Nadir \\
\hline Kardiyovasküler semptomlar & Sık & Daha sık \\
\hline $\begin{array}{l}\text { Pulmoner semptomlar } \\
\text { (KOAH, interstisyel pnömoni, } \\
\text { parankimal akciğer hastalığı) }\end{array}$ & Nadir & Nadir \\
\hline $\begin{array}{l}\text { Ürogenital belirtiler (renal } \\
\text { yetmezlik, renal taşlar, } \\
\text { nefrotik sendrom) }\end{array}$ & - & Nadir \\
\hline
\end{tabular}

Abdominal Ağrı ve Kramp: Hastaların \%70’inden fazlasında görülen majör semptomlardan biri olup; hastalar tarafindan "en çok acı veren semptomlardan biri” olarak ifade edilmektedir. Ağrı, hastalık aktivitesi ile ilişkili olmayıp; klinik ve/veya endoskopik re- 
misyondaki hastaların \%20-50'sinde ağrı yakınması görülmektedir.Diğer yandan, abdominal ağrının ilk tedavisinde inflamasyonun tedavisi çok önemlidir, çünkü hastaların \%50-70'i hastalık alevlenmesi sırasında da karın ağrıları yaşamaktadır ${ }^{13,34}$. Aminosalisilatlar ve oral demir preparatları gibi İBH tedavisinde kullanılan bazı ilaçlar da abdominal ağrıya yol açabilmekte, bu durumda yaşanılan ağrı, hastayı diğer IBH semptomlarından daha çok etkiliyorsa tedavi kesilmelidir. Striktür, fistül ve karın içi apseler gibi hastalık komplikasyonları karın ağrısına katkıda bulunabilir. Daralma olan hastalarda düşük lifli, sıvı gıdalarla diyet değişiklikleri yapılabilir. Fistüllerin agresif tedavisi yapılmalıdır ${ }^{4}$. Anksiyete, depresyon ve diğer eşlik eden psikiyatrik durumlar, viseral aşırı duyarlılikta rol oynayabilir ve İBH tanılı hastalarda fonksiyonel karın ağrısına katkıda bulunabilir ${ }^{13,22,35}$.

Inflamatuar barsak hastalıklarında abdominal kramp daha sık görülür. Barsak segmentindeki darlığa bağl1 olarak ortaya çıkan ağrı; defekasyondan önce kramp şeklinde belirmekte ve defekasyonla geçmektedir. Ağrı ile birlikte karında "gurultu" sesleri duyulmaktadır. Crohn hastalığında kramp tarzı ağrı daha sık görülmektedir. Terminal ileuma sınırlı olan hastalıkta genellikle sağ alt kadranda kolik tarzda ağrı ve distansiyon görülür. Buna bulantı ve kusma da eşlik edebilir. Özellikle sağ kolon tutulumlu CH'de ağrı, periumblikal olabilir veya alt kadrana yayılabilir. Ateş ile birlikte görülen ağrı, iştah kaybına ve kilo kaybına neden olabilir ${ }^{4-6,10,23-25,34}$.

Dışkıda Kan: Crohn hastalığında dışkıda sıklıkla mikroskopik düzeyde kan gözlense de büyük kanama ÜK'deki kadar sık değildir. Ülseratif kolit hastalarında karakteristik olan bu bulgu, genellikle dışkıdan ayrı veya normal kıvamda dışkının üzerine bulaşmış kan gelmesi niteliğindedir. Sadece rektal tutulumu olan ÜK hastalarında rektal kanama, acil defekasyon yapma isteği, tenezm ve nadir olarak karın ağrısı ile birlikte görülebilmektedir ${ }^{6,25,35}$.

Acil Defekasyon İsteği (Tenesmus): Rektum tutulumu olan ÜK hastalarında daha fazla görülmektedir; CH'na bağlı gelişen proktitiste ise nadiren görülmektedir. Tenesmus ve hematokezya birlikteliğinde rektal prolapsus düşünülmelidir ${ }^{6,12,26}$.

İştah ve Kilo Kaybı: Crohn hastalığında daha belirgin olup, malabsorbsiyona, gida alımının azalmasına ve kusma sonucu ortaya çıkabilmektedir. Malabsorbsiyon ve oral alımın azalması sonucu birçok Crohn hastası \%20'den fazla kilo kaybı yaşamaktadır. Emosyonel stres, enfeksiyon, gebelik, uygunsuz diyet programları, akut ya da kronik başka inflamatuar hastalık dönemlerinde İBH'de rekürrensler ve alevlenmeler görülebilmektedir ${ }^{5,35}$.

\section{IBH'de Ekstraintestinal Semptomlar}

Hemen her sistemi etkileyebilen ekstraintestinal semptomlar barsak dışı semptomlardır ve İBH olan hastala- rın \%21-36'sında meydana gelmektedir. Bu semptomlar; İBH varlığı veya tedavisinin bir sonucu olarak ortaya çıkmakta, hastalık aktivitesi ile ilişkili olabilmektedir $^{5,6,10,12,13,23,26,27,36-39}$ :

Bulantı ve Kusma: Bulantı ve kusma, ÜK hastalarının \%30'undan fazlasında ve aktif CH'nin \%69'unda görülmektedir. İBH tedavisinde kullanılan ilaçlar, özellikle de immünmodülatörler bulantı ve kusmaya yol açabilir. Metotreksatın CH'nin indüksiyonu ve remisyonundaki etkinliğini değerlendiren bir sistematik derlemede en yaygın semptomların bulantı ve kusma olduğu rapor edilmiştir. Bulantı ve kusmanın genellikle hafif seyrettiği ve ilacın kesilmesi veya folik asit takviyesi ile düzeldiği ifade edilmiştir ${ }^{5,6}$. Barsak obstrüksiyonu, enfeksiyöz gastroenterit de dahil olmak üzere gastrointestinal sistem enfeksiyonları varlığında hastalar bulantı yaşayabilirler. Ayrıca kusma, CH'de cerrahi için ön bulgu olabilmektedir ${ }^{5}$.

Ateş, Yorgunluk, Gece Terlemeleri: Çoğu hastada ateş düşük seyretmektedir. Şiddetli ÜK atakları sırasında ateş olabilmekte, bununla birlikte titreme, anemi, hipoalbuminemiye bağlı olarak halsizlik, yorgunluk bulunabilmektedir. Komplikasyonlar geliştiğinde ateş daha da yükselir ve gece terlemeleri eşlik edebilir.

Halsizlik, enerji eksikliği gibi yakınmaların dinlenmekle veya uyku ile rahatlamaması, bitkinlik hissi olarak tanımlanan yorgunluk; fiziksel, duygusal, bilişsel ve sosyal yaşam gibi birçok yönden yaşam kalitesini etkileyebilmektedir. İBH tanılı hastaların genel popülasyonla karşılaştırıldığında daha yüksek oranda yorgunluk yaşadığı belirtilmektedir. Hastalığın aktif döneminde hastalar sıklıkla yorgunluktan yakınmaktadırlar. Ancak remisyonda olan hastaların da \%40'ından fazlası yorgunluk yaşamaktadır ${ }^{38-41}$. Hastalığın aktifleşmesi, anemi, nütrisyonel veya metabolik yetersizlikler, irritabl barsak sendromu benzeri fonksiyonel bozukluklar, anksiyete, depresyon ve uyku bozuklukları İBH'de yorgunluğun nedenleri arasında yer almaktadır, 41,42. Yorgunluk semptomunun yönetiminde, yorgunluğa neden olan durumların tanımlanması ve ortadan kaldırılması/iyileştirilmesi etkili olmaktadır. Örneğin; nutrisyonel bozuklukların tanılanması ve tedavisi (demir ve $\mathrm{B}_{12}$ vitamin takviyeleri) İBH tanılı hastalarda yorgunluğun iyileştirilmesine yardımcı olmaktadır. Ayrıca daha iyi bir uyku kalitesi, psikolojik faktörlerin iyileştirilmesi, anksiyetenin giderilmesi, stresle baş etme becerilerinin geliştirilmesi ve çözüm-odaklı terapiler hastaların yorgunluğunun azalmasına yardımcı olmaktadır ${ }^{4,43}$.

Anemi: İnflamatuar barsak hastalıklarında sık rastlanan ekstraintestinal bulgulardan biri olan anemi, kronik demir eksikliği ve kronik hastalık anemisi şeklinde görülmektedir. Anemi İBH tanılı hastaların yaşam kalitesi üzerine oldukça etkilidir ${ }^{12,13,26,27}$. Demir eksikliğinin tanısı inflamasyonun düzeyi ile ilişkilidir. Klinik, endoskopik veya biyokimyasal belirtileri olmayan hastalarda serum ferritin düzeyinin $<30 \mu \mathrm{g} / \mathrm{L}$ olmas1 tanı koydurmaktadır. İBH tanılı tüm hastalar anemi 


\section{İBH ve Semptom Yönetimi}

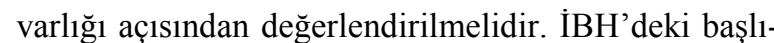
ca anemi formları demir eksikliği anemisi ve kronik hastalık anemisidir ${ }^{12,26,27}$

Kronik gastrointestinal kan kaybı, kronik hastalık, folat eksikliği, vitaminB $B_{12}$ eksikliği veya otoimmün hemolitik anemi nedeniyle demir eksikliği anemisi veya kronik hastalı anemisi görülmektedir. IBH'de özellikle CH'de üst gastrointestinal sistem tutulumunda, tedavide kullanılan sülfosalazin vemetotreksat nedeniyle folat emiliminde azalma meydana gelmektedir. Farklı etiyolojik nedenlerden dolayı, İBH'de anemiye yol açan etkenler, anemi tanısı, türü ve tedavisi oldukça önemlidir ${ }^{26,27}$.

Anemisi olan hastalarda, tam kan sayımı, serum ferritin ve C-reaktif protein incelemeleri yapılmalıdır. Remisyonda ya da orta şiddetli hastalarda, 6-12 ayda bir bu ölçümler tekrarlanmalıdır. İntravenöz demir; aktif şiddetteki hastalarda, oral demir tedavisini tolere edemeyenlerde ve hemoglobin düzeyi $10 \mathrm{~g} / \mathrm{dl}$ 'nin altında olanlarda ilk tedavi seçeneği olmalıdır ${ }^{12,44}$. Aneminin yönetiminde ayrıca etiyolojik etkene göre beslenme planı oluşturulmalı, demir eksikliği anemisi varsa demir içerikli gıdaların, folat eksikliği varsa folat içeren gıdaların gün içinde daha fazla tüketilmesi sağlanmalıdır.

Artropati ve Artralji:İBH'de periferik artrit, inflamatuar bir artropatidir. Periferik artrit periferik eklemleri tutar, hasta eklem şiş ve ağrılıdır. İnflamatuar barsak hastalığının en sık görülen ekstraintestinal bulgusu kolitik artrit ve ankilozan spondilittir. Ankilozan spondilit sabah sertliği, aksiyal tutulum, hareketle azalan sırt ve bel ağrısı ile karakterizedir ${ }^{10,12,37}$. Periferal ve aksiyal artropatiler hem ÜK’te (\%4-23 oranında) hem de CH'de (\%25-35 oranında) görülmektedir. Ancak artropati İBH'de artraljiden daha s1k görülmektedir. Aksiyal hastalık İBH'nin tüm formlarında ve her iki cinsiyette de eşit oranda görülürken; periferal artropati CH'de ve kadınlarda daha sıktır. Tip 1, özellikle alt ekstremitenin büyük ağırlık taşıyan eklemleri olmak üzere, beşten az eklemleri etkileyen şişlik veya efüzyon bulgularına sahip eklem ağrısı olarak tanımlanır. Semptomlar kalıcı eklem hasarı olmadan genellikle akut ve 10 haftadan az olup, İBH alevlenmesiyle ilişkilidir. Beşten fazla eklemi etkileyen tip 2, simetrik bir dağılım gösterir, çoğunlukla üst ekstremiteyi tutar ve aylarca-y1llarca sürebilir ${ }^{10,12,16}$.

Artropati ve artralji semptomlarının yönetiminde yoğun fizyoterapi ve kısa süreli non-steroid antiinflamatuar ilaç (NSAIII) tedavileri etkilidir. Sulfasalazin ve metotreksat sınırlı etkilidir; bu nedenle erken dönemde antitümör nekroz faktörü [anti-TNF], NSAIII'leri tolere edemeyen veya dirençsiz hastalar için tercih edilen tedavi seçeneğidir ${ }^{16}$.

Metabolik Kemik Hastalığı: Osteoporoz tanısı radyografik kemik dansitometre skoru ile (T-skor< -2.5) konulmaktadır. Düşük kemik kitlesi ve osteoporoz $\mathrm{CH}$ olanlarda \%40-50 oranında görülmektedir. Kronik inflamasyon, kortikosteroid tedavisi, kısa barsak hastalığı veya rezeksiyon yaşı, kadın cinsiyet, sigara kullanımı, düşük fiziksel aktivite ve beslenme yetersizlikleri, beden kitle indeksinde azalma, daha önceki fraktür öyküsü, CH'de kemik hastalıklarının etiyolojik faktörleridir. Hem azalmış hem de normal kemik yoğunluğu olan hastalarda vertebra kırığı, İBH tanılı genç hastalarda osteoporoz için ana risk faktörüdür. Ancak kalça kırıkları, vertebra fraktürlerinden daha sık olup, genel popülasyondan $\% 27$ daha fazla$\operatorname{dir}^{12,17,18,20}$.

Metabolik kemik sorunlarının yönetiminde sistemik steroid tedavisi alan hastalara kalsiyum ve D vitamini takviyelerinin yapılması, ağırlık kaldırma egzersizleri, sigarayı bıraktırma ve günde $1 \mathrm{~g}$ kalsiyum takviyesi ile metabolik kemik kaybını önlemede etkilidir ${ }^{12,16}$.

Göze İlişkin Semptomlar: Üveitis, göz kuruluğu, blefarit ve episklerit İBH'nin sık görülen (\%12) oküler semptomlarındandır. Bazı oküler semptomlar tedaviye sekonder ortaya çıkarken, bazıları barsaktaki hasarın etkisiyle gelişmektedir. Episklerit barsaktaki hastalık aktivitesini gösterirken; üveit barsak semptomlarından ve diğer ekstraintestinal semptomlardan bağımsız olabilir ve üveit tanısını takiben İBH ortaya çıkabilmektedir. CH'da görülen üveit sıklıkla bilateral, sinsi başlangıçlı ve uzun süreli olup, \%2-13 oranında görülmektedir. Kadınlarda daha sık izlenir. Klasik belirtileri; sklera ve konjuktivada hiperemi, göz ağrısı, kaşıntı, yanma, bulanık görme, fotofobi ve baş ağrısı$\operatorname{dir}^{10,12,16}$.

Episkleritin semptomatik tedavisinde topikal veya sistemik NSAİI’ler, yanı sıra immünsupresyon ve anti-TNF ajanlar uygulanmalıdır ${ }^{16}$.

Oral ve nazal hastalıklar: Aftöz ülserler İBH'de en sik izlenen (\%10) oral lezyonlardır. İntestinal hastal1ğın alevlenmesiyle birlikte, genellikle ani başlangıçl1dır. Crohn hastalığı tüm GİS alanlarında tutulum yapmakla birlikte, oral tutulumlu CH'de derin ülserasyonlar, psödopolipler ve dudaklarda veya ağız boşluğunda şişme görülmektedir. Bu durumlar genellikle perineal hastalıkla ilişkilidir ve uzun süreli bir seyri vardır. Aseptik nazal septal apsenin ise ÜK ile ilişkili olduğu bildirilmiştir $^{16}$.

Deri hastalıkları: En sık görülen deri lezyonları; pyoderma gangrenosum ve eritema nodosumdur.Cilt biyopsisi ile tanılanabilen eritema nodosum (EN),1-5 cm çapında, kabarık, hassas, kırmızı veya mor renkli deri altı nodülleri ile karakterizedir.Ülseratif kolit hastalarının \%3'ünde, $\mathrm{CH}^{\prime}$ de ise hastaların \%15'inde görülmektedir. Skar bırakmadan iyileşmektedir. Soliter veya çoklu nodüller, plaklar ve ülserler ayırıcı tanıya götürür. Daha çok kol ve bacakların ön yüzeyini, özellikle ön tibial bölgeleri etkiler. Genellikle İBH alevlendiğinde meydana gelmektedir. Kadınlarda ve CH'de daha yaygındır ${ }^{10,12,16,36,38,39}$. 
Pyoderma gangrenosum (PG) ise genital bölge de dahil olmak üzere vücudun her bölgesinde, sıklıkla bacaklarda ve stomaya yakın yerlerde görülebilir. Ülseratif kolit hastalarının \%0.4-2'sinde, Crohn hastalarında ise \%1-4'ünde görülmektedir. Başlangıçta eritematöz papüller ve püstüllerle ortaya çıkar, daha sonra dermisin nekrozu ile derin ülserlere dönüşmektedir. Ağrılı nodül veya püstül şeklinde başlayan lezyonlardan kenarları deriden kabarık, dokunmakla hassas, kenar kısımlarının altı oyuk, giderek genişleme eğilimi gösteren 2-20 cm çapında ülser gelişmektedir. $\mathrm{Bu}$ derin ülserler tendonlar, kaslar ve derin dokularda ortaya çıkabilmektedir. Akut ÜK'de hemen her zaman gelişmektedir ${ }^{10,12,16,36,38,39}$.

İBH'de uygulanan tedaviler de bazı durumlarda deri ile ilgili sorunlara yol açabilir. Anti-TNF ilişkili deri lezyonları hastaların \%22'sinde görülmektedir. İmmünomodülatörler ve anti-TNF kullanımına bağlı olarak; enfeksiyon, malignite, alerjik reaksiyonlar ve paradoksal inflamasyon gibi kutanöz yan etkiler ortaya çıkabilir. Anti-TNF tedavisi alan İBH hastalarında psoriatik ve ekzematöz lezyonlar (egzama ve kseroz) en s1k gözlenen cilt lezyonlarıdır ${ }^{12,45,46}$. Rahier ve arkadaşlarının yaptığı çalışmada (2010); 85 hastanın 62'sinde psöritik ve egzamatoz lezyonlar geliştiği, lezyonların sıklıkla kafa derisinde yer aldığı, deri lezyonlarının İBH aktivitesi ile ilişkili olmadığ $\breve{g}_{1}$ belirtilmiştir ${ }^{46}$.

Eritema nodosum ve pyoderma gangrenosum tedavisi altta yatan İBH'nin tedavisine dayanmaktadır. Ağır vakalarda sistemik kortikosteroid ile, tekrarlayan ve dirençli vakalarda immünomodülatörler (azatioprin, infliksimab, adalimumab) veya anti-TNF ile tedavi edilebilir. Anti-TNF ile ilişkili deri lezyonlarının yönetiminde ise genellikle ilacın kesilmesi gerekmektedir. Çoğu vaka topikal tedavi ile kontrol altına alınmakta ve sonrasında tedaviye devam edilmektedir (16).

Hepato-pankreato-biliyer hastalık (Primer sklerozan kolanjitis-PSK): İBH tanılı hastaların \%30'undan fazlasında karaciğer fonksiyon testleri değişmiştir. Bu değişimlerde PSK, ilaca bağlı veya İBH'den bağımsız karaciğer hastalıkları mutlaka düşünülmelidir. PSK, İBH'ye özgü olarak en sık görülen karaciğer hastalığ1 olup, hastaların \%4-5'ini etkilemektedir. ÜK'de ve erkeklerde daha sık görülmektedir. Karaciğer fonksiyonları normal olan hastalarda dahi biliyer darlık gözlenmiştir. PSK genellikle asemptomatik olup, spesifik olmayan kırıklık, kaşıntı, ateş, üşüme, gece terlemesi ve sağ üst kadran ağrısı gibi semptomlarla karakterizedir. PSK olan İBH tanilı hastalarda kolorektal kanser riski, PSK olmayan İBH'lilerle karşılaştırıldığında daha yüksektir. PSK ve İBH'li hastaların \%55-95'inde geniş kolit, \%10-15'inde ise kolorektal karsinom gelişmektedir. PSK yaygın olarak ÜK ile ilişkilendirilmektedir; ÜK hastalarının \%2-5'inde PSK izlenirken, PSK hastalarının \%75'inde ÜK bulunmaktadir ${ }^{10,12,16,47}$
PSK veya küçük kanal PSK'de karaciğer transplantasyonunu, kolanjiyokarsinomu veya ölüm riskini azaltan herhangi bir tıbbi tedavi gösterilmemiştir. Semptoma yönelik ursodeoksikolik asit karaciğer fonksiyonlarını bir miktar iyileştirebilir, ancak yüksek dozlardan kaçınılmalıdır. Hastada otoimmün hepatit varsa kortikosteroidler ve/veya immünsupresif ajanlar düşünülmelidir. İH ve PSK bir arada bulunan hastalarda safra kanal kanseri riskinde artış kadar karsinom riski de artmıştır; bu nedenle hastalarda yıllık kolonoskopi taramalarının yapılması önerilmektedir ${ }^{12,16,47}$.

PSK Dışındaki Karaciğer Hastalıkları: Non-alkolik yağlı karaciğer, ÜK hastalarının \%1,5-55'inde, CH'nın \%1.5-39.5'inde görülmektedir (ortalama prevalans \%23). Risk faktörleri; metabolik sendrom veIBH ile ilişkili faktörlerdir (intraabdominal abse, fistül, hastalık şiddeti, malnütrisyon, protein kaybı, kortikosteroid veya metotreksat gibi ilaçlar). İlaç kaynaklı karaciğer hasarı İBH hastalarında nadir görülmekle birlikte (genellikle 5-aminosalisilik asit [5-ASA] ilaçlarının kullanımına bağlı olarak) orta şiddette gelişebilmektedir, kronik hepatite dönüşebilir. Hastalarda 13 ayda bir karaciğer fonksiyon testlerinin yaptırılması önemlidir. Portal ven trombozu da İBH'nin ciddi komplikasyonlarından biridir ve postoperatif dönemde daha s1k görülmektedir. Granülomatoz hepatit ise CH'nin, ilaç kaynaklı karaciğer hasarının, siroz, sarkoidoz veya Weegener hastalığı gibi inflamatuar bir başka hastalığın, lenfomanın ekstraintestinal semptomlarından biri olarak görülmektedir ${ }^{12,16}$.

Portal ven trombozunun yönetimi için hastanede yatış sirasında tromboembolizmi veya İBH alevlenmelerini önlemeye yönelik girişimler uygulanmalıdır. Tanı konduktan sonra, hem altta yatan İBH ile ilişkili protrombotik durumlar hem de genetik trombofili için riskler değerlendirilmelidir. Kilavuzlarda antikoagülan tedavi önerilmektedir ${ }^{16}$.

Pankreatit: Akut pankreatit genellikle safra taşı, alkol alımı, ilaç yan etkileri [özellikle azatiyoprin ve 6merkaptopürin] ve duodenal $\mathrm{CH}$ ile ilişkilidir. İBH hastalarında kronik pankreatite bağlı ağrı nadirdir. Buna karşın, pankreas ekzokrin yetmezliği ve pankreas kanalı anormallikleri daha sık görülmektedir. Akut pankreatit insidansı CH'de \%4 iken, ÜK'te \%1.5-2'dir. İBH tanılı hastalarda akut pankreatitin klinik görünümü İBH olmayan pankreatit vakalarıyla aynıdır. Üst abdominal ağrı, serum lipaz düzeyinde artış, amilaz düzeyinde azalma (bu üç kriterden en az ikisinin varlığ 1 ) tanı koydurucudur ${ }^{16}$.

İBH'de kronik pankreatit; pankreas kanalı anormallikleri ve çoğu durumda parankimatöz kalsifikasyonların olmaması ile karakterizedir. Pankreas kanalı değişikliklerinin prevalansı $\mathrm{CH}^{\prime} \mathrm{de} \% 8$, ÜK da \%16'dır. Pankreatitin tedavisi, İBH'li pankreatit hastaları için de geçerlidir ${ }^{16}$.

Nörolojik hastalıklar (Periferal nöropati): Merkezi sinir sistemi belirtileri İBH hastalarında genel popü- 


\section{İBH ve Semptom Yönetimi}

lasyona göre daha yaygın olabilir. Periferik nöropati İBH'de oldukça nadirdir. Dikkate alınması gereken nedenler; venöz sinüs trombozu, inme ve santral demiyelinizasyondur. Ayrıca, anti-TNF tedavisi ile periferik nöropati kötüleşebileceğinden, merkezi sinir sistemi hasarı olan hastalarda anti-TNF ilaçlar kontrendikedir ${ }^{16}$.

Gondim ve arkadaşlarının (2005) 33 İBH hastasını inceledikleri bir vaka serisinde,orta yaş (50’li yaşlar) erkek hastalarda periferik nöropatinin parestezi ve ağriya neden olan duyusal liflerin de etkilendiği tablonun daha fazla görüldüğü, hastaların şık \%30'unda demyelinize nöropatinin olduğu belirlenmiştir. Ayrıca demiyelinizan nöropatinin kadınlarda proksimal ve distal simetrik zayıflık ve distal duyusal bozukluk ile orantılı olarak daha yaygın olduğu belirtilmiştir ${ }^{48}$.

Figueroa ve arkadaşlarının bir çalışmasında (2013); 18-91 yaş arası İBH tanılı 772 hastanın 9'unda periferik nöropati geliştiği, genel insidans oranının İBH popülasyonu için \%72 olduğu, İBH tanısı aldıktan 144 yıl sonrasında periferik nöropati geliştiği, bunun İBH aktivitesi ile ilişkili olmadığı ifade edilmiştir ${ }^{49}$.

Periferik nöropatinin tedavisinde, nörolojik yan etkileri olan ilaçların (metronidazol, sulfasalazine, antiTNF) kesilmesi önerilmektedir. Yanı sıra komorbiditeleri tedavi etmek ve vitamin seviyelerini normalleştirmek de hastalarda nöropatiye ilişkin yakınmaları azaltacaktır.

Periferik nöropati genellikle İBH aktivitesiyle ilişkili olmadığ için, altta yatan barsak aktivitesinin tedavisi nöropatiyi iyileştirmez ${ }^{16}$.

Kardiyovasküler semptomlar: Crohn hastalığı ve ÜK'de benzer oranlarda olmak üzere, iskemik kalp hastalığı, serebrovasküler olay ve mezenterik iskemi riski,özellikle de kadınlarda oldukça yüksektir. Romatoid artritte olduğu gibi, İBH'de de sistemik inflamasyonun varlığı erken aterosklerozun ve koroner arter hastalığının predispozan etkenidir. İBH'de erken ateroskleroz inflamasyon, endotel disfonksiyonu, kalsifikasyon ve hiperkoagülabilitenin bir kombinasyonu olarak görülmektedir ${ }^{16,50,51}$

Venöz tromboembolizm İBH aktivitesi ile ilişkili olup, genel popülasyona oranla İBH hastalarında en az 2 kat daha fazladır. $\mathrm{Bu}$ nedenle de tüm İBH hastaları için profilaksi önerilmektedir ${ }^{10,16,37}$.

İH tedavisinin, inflamatuar aktiviteyi baskılayarak kardiyovasküler riski azaltılabileceği tahmin edilmektedir. 5-ASA,tiyopürin ve anti-TNF ajanları tek veya kombine olarak kullanan hastalarda, kullanmayanlara oranla iskemik kalp hastalığı daha düşüktür ${ }^{52}$.

Vizzard ve arkadaşlarının çalışmasında (2016); hastaların \%25.7'sinde mitral kapak su, \%50.0'sinde mitral kapakta kalınlaşma saptanmış, ayrıca $\mathrm{CH}$ ve ÜK arasında ekokardiyografik göstergeler açısından bir fark olmadığ $\breve{g}^{\text {belirlenmiştir }}{ }^{50}$.
Kardiyovasküler semptomların yönetiminde erken tanı kardiyovasküler komplikasyonları önlemeye ve hastalığın doğal seyri üzerindeki etkiyi en aza indirmeye yardımcı olmaktadır. Kardiyovasküler manifestasyonlar için primer koruyucu önlemlerden en önemlileri; remisyonun mümkün olduğu kadar uzun süre korunmas1, kardiyolojik periyodik değerlendirmelerin yapılması (fizik muayene, kan testleri, elektrokardiyogram ve transtorasik ekokardiyografi), yüksek tromboembolik olay riski olan hastaların antikoagülasyonu ve kardiyovasküler risk faktörlerinin yönetimidir ${ }^{12,16}$.

Pulmoner semptomlar: Glottisten küçük havayollarına kadar bronşiyal ağacın farklı bölümlerine yerleşmiş farklı bronkopulmoner hastalıklar İBH'de nadir görülen enkstraintestinal bulgulardandır. İBH ile ilişkili interstisyel pnömoni ve KOAH görülmektedir. Enfeksiyonlar veya ilaçlar [salisilatlar, metotreksat, tiyopurinler, anti-TNF] parankimal akciğer hastalığına neden olabilmektedir. Kortikosteroid, immünomodülatör ve/veya anti-TNF tedavisi alan hastalarda solunum semptomları göz ardı edilmemelidir, çünkü bunlar ciddi bir fırsatçı enfeksiyonun başladığını gösterebilir. İlaç ilişkili akciğer hastalıkları 5-ASA veya metotreksat kullanımına bağlı olarak ortaya çıkmakta ve dispne, ateş, göğüs ağrısı, öksürük en sık görülen semptomlarıdır. İBH'de bronkopulmoner tutulum ise geniş bir alanı kapsamaktadır. Sıklıkla glottisten küçük hava yollarına kadar olan alanda havayolu inflamasyonu, bronşektazi görülür. Bunun yanı sıra kolon ameliyatı olan hastalarda kalıcı havayolu inflamasyonu havayolunungeri dönüşümsüz olarak daralmasına ve buna bağlı subglottik - trakeal darlıklara, kronik bronşite, bronşektazi veya bronşiyolite neden olabi$\operatorname{lir}^{16,17,47}$.

Havayoluna ilişkin semptomların yönetiminde öncelikle ilaç kaynaklı pulmoner hastalıklar varsa bunlar dışlanmalıdır. Salisilat veya metotreksat alan hastalarda ilacın kesilmesi önerilmektedir. İBH ile ilişkili havayolu değişikliklerinin çoğunda kortikosteroid sorumludur. İnhale kortikosteroidler (budesonid) özellikle büyük havayolu tutulumlarında etkili olurken; sistemik kortikosteroidler parankimal tutulumda ve inhale kortikosteroidlere dirençli hastalarda kullanılmaktadır. Steroid direnci veya yüksek doz steroid bağımlı refrakter akciğer hastalığı olan İBH hastalarında, immünomodülatörler ve/veya biyolojik ajanlarla tedavi edilmelidir. CH'na bağlı ortaya çıkan akciğer hastalığında ise Anti-TNF tedavisi etkili olmakta$\mathrm{dir}^{38,47}$.

Ürogenital semptomlar: Renal yetmezlik prevalansı CH'de \%2 olup, rezeke edilmiş ince barsak uzunluğu, yaş, hastalık süresi ve böbrek taşı öyküsü risk faktörleridir. İBH'de, özellikle CH'de ürik asit veya kalsiyum oksalat taşları görülebilmektedir. Nadir de olsa sulfasalazin ve 5-ASA tedavileri renal toksisiteye (glomerülonefrit, nefrotik sendrom, interstisyel nefrit) yol açabilmektedir. Siklosporin, afferent arteriollerde 
daralma nedeniyle akut böbrek yetmezliğine, böbrek kan akışında ve glomerüler filtrasyon hızında azalmaya yol açabilmektedir. Renal yetmezlik ateş, eozinofili ve döküntü ile seyredebilir. Ancak tedavinin kesilmesini takiben 5-7 gün içerisinde normale dönmektedir. Tanı geciktiği durumlar dışında, böbrek hasarı geri döndürülebilmektedir ${ }^{5,6,10,16}$.

Ürogenital semptomlara bağlı olarak renal yetmezlik yaşayan İBH tanılı hastalarda tedavinin başında yüksek risk nedeniyle, ilk üç ay boyunca ayda bir veya ilk yıl her üç ayda bir, sonrasında yılda bir böbrek fonksiyonları değerlendirilmelidir ${ }^{10,18}$.

Genel olarak İBH ilişkili intestinal ve ekstraintestinal semptomların yönetiminde; hastanın bireysel ve hastalığa ilişkin özellikleri dikkate alınarak etkili olmayan ya da semptomları ortaya çıkaran ilaçları doktora bildirilmeli, semptomlar iyileşene, alevlenme süreci gerileyene kadar hasta s1k s1k değerlendirilmeli ve hasta ile sürekli iletişim halinde olunmalıdır.

Inflamatuar barsak hastalarının semptom yönetimine dair önerilen hemşirelik girişimleri ${ }^{3,4,12,17-22,28,29-}$ $33,44,47,53$.

- Hastaya; düzenli bir şekilde doktor kontrollerine gitmesi, sağlıklı ve dengeli beslenmesi, düzenli ilaç kullanması, egzersiz yapması, sigarayı bırakması ve stresi azaltmaya yönelik planlamalar yapması konularında kapsamlı bir eğitim verilmelidir.

- Anal bölgede irritasyonu azaltmak için el duşu kullanılması, anal bölge hijyeninin sağlanması ve tuvalet sonrası temizlikte nemli havlu kullanımı önerilmelidir. İrritasyon oluştuysa temizlik sonrası A ve $D$ vitaminli bir krem kullanılabilir.

- Anal ağrı, fissür veya fistülü olan hastalara 1 lık oturma banyosu önerilebilir.

- Eklemlerle ilişkili sorunlarda etkilenen eklem dinlendirilmelidir.

- İnflamasyon geçtikten sonra, remisyon sürecinde eklem hareketlerinin geliştirilmesi ve iyileştirilmesi için ROM egzersizleri yaptırılmalıdır.

- Ağız içi yaraları azaltmak için gargara solüsyonları ile ağız bakımı, dengeli bir beslenme ve eksikliklere göre vitamin / mineral takviyeleri önerilebilir.

- Ağrı semptomunun yönetimi için doktor istemine göre farmakolojik ajanlar uygulanabilir. Ayrıca uygun non-farmakolojik yöntemler de önerilebilir.

- Hastanın kendi bakım ve gereksinimlerinin farkında olması, iyi uyuması, stresi yönetme becerileri kazanması sağlanmalıdır.

- Bazı hastalarda semptomlar günün belirli saatinde aktifleşebilir. Hastanın bu saatleri bilmesi, günlük planlamalarını bu saatlere göre yapmasına yardımc1 olabilir.

- İnkontinans hastalarda utanma duygusuna ve bu nedenle de sosyal izolasyona neden olabilir, bu nedenle bazı önlemlerin alınması faydalı olabilir: o Yedek çamaşır ve kıyafet, tuvalet kağıdı, temizleme mendilleri, el sabunu ve çöp torbası içeren "acil tuvalet çantası”" hazırlanabilir.

o Bir seyahat planı çıkarılarak yol güzergahındaki tuvaletler, dinlenme odaları, restoranlar ve alışveriş merkezleri belirlenerek endişe ve stres azaltılmalıdır.

o Gerektiğinde yardım talep edebileceği bir arkadaşı veya aile üyesi olması ve onların da inkontinans durumuyla ilgili olarak bilgilendirilmesi önerilebilir.

- Yorgunluk hastalığın alevlendiğini gösteren, bazen yönetilebilen, bazen de hastayı zayıf düşüren önemli bir bulgudur. Ciddi yorgunluk yakınması olan hastaların, enerjiyi koruma teknikleri konusunda bilgilendirilmesi gerekmektedir.

o Hasta gücünün sınırlarının farkında olmalıdır.

o İhtiyaç duyduğunda uyumalı veya dinlenmelidir.

o Bir aktiviteye katılması veya bir iş yapması gerekiyorsa öncesinde ve sonrasında mutlaka dinlenmeye zaman ayırmalıdır.

o Doktorun önerisine göre gerekirse vitamin takviyesi alınabilir.

o Hastanın günlük işlerini planlarken günün en dinamik olduğu sabah saatlerine göre planlama yapması önerilebilir.

- Aynı hastalığa sahip bireylerle sosyal destek gruplarına katılması sağlanabilir.

- Çalışan bir hasta ise işveren ya da amiriyle hastalığ1 ve kendisini nasıl etkilediği hakkında konuşması sağlanmalıdır.

- Eğitim dönemindeki genç ve çocuk hastaların ihtiyaç durumunda dersten çıkmasına izin verilmeli, gün içinde dinlenebileceği bir ortam sağlanmalı ve revir hemşiresi öğrenci hakkında bilgilendirilmelidir. Revirde hastanın ilaçlarının yedeği ve acil tuvalet çantası bulundurulması konusunda hasta ve ailesiyle işbirliği yapılmalıdır.

- Hastalar semptom kontrolü için tamamlayıcı ve alternatif yöntemlere de başvurmaktadır. Sıklıkla başvurulan yöntemler arasında; başta bitkisel ürünler olmak üzere relaksasyon, hipnoz, biyolojik geri bildirim (bio-feedback), akupunktur, akupressüre, yoga, meditasyon, masaj, müzik ve refleksoloji, kriyoterapi ve aromaterapi yer almaktadır. Ancak bu yöntemlerin tıbbi tedavi yerine değil, doktorun bilgisi ve önerisi dahilinde tıbbi tedavi ile birlikte yürütülebileceği anlatılmalıdır.

- Hastalık alevlenme ve remisyon dönemlerine göre beslenme planlarında yapılması gereken değişimler anlatılmalidir.

- Hastaların gereksinimi olan konularda taburculuk eğitimi planlanmalı, yazılı ve görsel eğitim materyalleri ile bilgi gereksinimi desteklenmelidir.

- Bir "semptom günlüğü” oluşturularak, semptomun ortaya çıkış şekli, süresi, şiddeti, hangi durumla tetiklendiği, baş etme yöntemi vb bilgileri içeren bir kayıt sistemi oluşturulmalı ve böylece bir yandan 


\section{İBH ve Semptom Yönetimi}

sonraki kontrollerine ilişkin tıbbi bir izlem oluşturulurken, diğer yandan da hastanın farkındalığ desteklenmeli.

Stresle baş etme yöntemleri hastadan hastaya değişmektedir. Önemli olan hastanın kendisine en uygun olan yöntemi deneye-yanıla keşfedebilmesidir. Bunun için de hastanın; sakin kalmaya çalışması, bakış açısını değiştirmesi, endişeye yol açan döngüyü kırmaya çalışması ve umutsuzluğa kapılmasını önleyen bir yaklaşım benimsemesi öğretilmelidir. Stresle baş etmede kullanabilecekleri yöntemler (geri bildirimde bulunma, gevşeme ve solunum egzersizleri, yoga, gibi meditasyon uygulamaları, hipnoterapi, bilişsel davranış terapisi, vb) önerilebilir ${ }^{54}$.

Inflamatuar barsak hastalarının tedavi ve bakım sürecine dahil olmaları çok önemlidir. Bu sayede hastaların evde kendilerinin alabilecekleri bir takım önlemler bulunmaktadır. Hafif düzeyde semptomları olan hastalar; bu semptomun ne zaman veya hangi etkene bağl1 olarak artış gösterdiğini tespit etmeleri (örneğin bir gıdanın tüketilmesiyle mi semptom meydana geldi? Ya da bir stres kaynağı mı tetikledi?) durumunda beslenme planlarında bazı değişiklikler yaparak, stresle baş etme yöntemlerini kullanarak veya bir destek grubundan (aile, arkadaş, vb) yardım alarak semptomun etkilerini yönetebilirler. $\mathrm{Bu}$ önlemlere karşın semptom şiddetinde bir iyileşme gözlenmiyorsa ya da giderek artış gösteriyorsa ilaç tedavisinde değişikliklerin yapılması gerekebileceğinden mutlaka doktora başvurması gerektiği hastalara öğretilmeli; kendi kendine ilaç doz ve sıklığında değişim yapmamaları konusunda bilgilendirilmelidir.

\section{Sonuç}

İnflamatuar barsak hastaları, yaşamları boyunca birçok semptomu farklı şiddetlerde yaşamaktadır. Bazı durumlarda semptomun etiyolojisi basittir, ancak bazen karmaşık ya da yönetimi güç olabilir. Birden fazla semptom yaşayan, aktif hastalık döneminde beslenme yetersizliği olan, psikolojik komorbiditeleri bulunan hastalarda kullanılan ilaçlar (özellikle immünmodülatörler) hastanın değerlendirmesini ve semptomların yönetimini daha da güçleştirmektedir. $\mathrm{Bu}$ gibi durumlarda, hemşirenin danışmanlık rolünü yerine getirmesi ve hızla hemşirelik sürecini başlatmas1 semptomların etiyolojisini belirlemek ve en uygun tedaviyi sağlamak için gereklidir. Tedavi edici yaklaşımların uzun sürdüğü veya mümkün olmadığı durumlarda, hastanın yaşadı ğı sorunları azaltmaya ve semptomlar nedeniyle düşen yaşam kalitesini iyileştirmeye yönelik yaklaşımlar uygulanmalıdır. Bu yaklaşımlardan biri olan semptom yönetimi; semptomları iyileştirmek - gidermek, önlemek veya en aza indirmeyi amaçlayan bir bakım yaklaşımıdır. Bu yaklaşımda hemşirenin hastayı bütüncül bir çerçevede değerlen- dirmesi ve etkileme düzeyi açısından her semptomu ayrı ayrı değerlendirmesi önem taşımaktadır. Özellikle İBH gibi alevlenme ve remisyon süreçlerinin birbirini izlediği kronik hastalıkların yönetiminde hasta gereksinimlerine odaklı, bireyselleştirilmiş bir bakım verebilmek için etkili bir semptom yönetimi sağlanmalıdır.Hasta bakımında hastaların yaşam kalitesini arttırmayı/iyileştirmeyi hedefleyen bir yaklaşım olarak semptom yönetiminin; kronik hastalıkla baş etme sürecinde İBH tanılı hastaların semptomlarını azaltacak ve remisyonda kalış sürelerini arttırmayı sağlayabilecek önemli ve etkili bir adım olduğu söylenebilir.

\section{Alana Katkı}

Bu makalede İBH tanılı hastaların bütüncül ve bireysel olarak değerlendirilmesini kolaylaştıran semptom yönetimine yönelik kanıt temelli girişimler ele alınmıştır. Makalenin İBH ve gastroenteroloji hekimlerine ve hemşirelerine rehberlik edeceği düşünülmektedir.

\section{Kaynaklar}

1. Tursi A, Elisei W, Picchio M. Incidence and prevalence of inflammatory bowel diseases in gastroenterology primary care setting. European J of Int Med. 2013;24:852-6.

2. Haapamaki J, Turunen U, Roine RP, Färkkilä MA, Arkkila PE. Finnish patients with inflammatory bowel disease have fewer symptoms and are more satisfied with their treatment than patients in the previous European survey. Scand J Gastroenterol. 2008;43:821-30.

3. Singh S, Blanchard A, Walker JR, Graff LA, Miller N, Bernstein CN. Common symptoms and stressors among individuals with inflammatory bowel diseases. Clin Gastroenterol Hepatol. 2011;9(9):769-75

4. Abraham BP. Symptom management in inflammatory bowel disease. Gastroenterol. Hepatol. 2015;9(7):953-67.

5. Tezel A. Bölüm: Crohn Hastalığında Klinik Özellikler, Belirtiler, Bulgular ve Doğal Seyir.İçinde: Akçal T, Yamaner S, Hamzaoglu İ, editörler. İnflamatuvar bağırsak hastalıkları. 2012 s: 35-45. ISBN:978-605-86701-0-5

6. Fitch M. Patient-initiated strategies for living with cognitive changes: implications for cancer nurses. Oncology Nursing Forum. 2007;34(2):580.

7. Harver A, Mahler DA. The symptom of dyspnea. In: Mahler DA, editör. Dyspnea. Futura, Mount Kisco, NY, 1990. p.1-53.

8. Dodd M, Janson S, Facione N, Faucett J, Froelicher ES, Humphreys J, et al. Advancing the science of symptom management. Journal of Advanced Nursing. 2001;33(5):668-76.

9. Carter MJ, Lobo AJ, Travis SPL. Guidelines for the management of inflammatory bowel disease in adults. Gut. 2004;53(Suppl 5):1-16.

10. Tezel A, Dökmeci G, Eskiocak M, Ümit H, Soylu AR. Epidemiological features of ulcerative colitis in Trakya. Turkey. J Int Med Res. 2003;31:141-8.

11. National Institute For Health and Clinical Excellence (NICE) Guideline. Crohn's disease management in adults. children and young people; 2012.

12. Magro F, Gionchetti P, Eliakim R, Ardizzone S, Armuzzi A, Acosta MB, et al. Third European Evidence-based Consensus 
on Diagnosis and Management of Ulcerative Colitis. Part 1: Definitions, Diagnosis, Extra-intestinal Manifestations, Pregnancy, Cancer Surveillance, Surgery, and Ileo-anal Pouch Disorders. Journal of Crohn's and Colitis, 2017;649-70.

13. Veloso FT. Extraintestinal manifestations of inflammatory bowel disease: do they influence treatment and outcome? Word J Gastroenterol. 2011;17(22):2702-7.

14. Symptom management. https://www.cancer.gov/publications/dictionaries/cancerterms/def/symptom-management Available Date: 20.10.2019

15. William SA, Schreier AM. The role of education in managing fatique, anxiety and sleep disorders in women undergoing chemotherapy breast cancer, Applied Nursing Research. 2005;18:138-47.

16. Harbord M, Annese V, Vavricka SR, Allez M, Acosta MB, Boberg KM, et al. The First European Evidence-based Consensus on Extra-intestinal Manifestations in Inflammatory Bowel Disease. J of Crohn's and Colitis. 2016:239-54

17. Levine JS, Burakoff R. Extraintestinal manifestations of in flammatory bowel disease. Gastroenterol Hepatol (NY). 2011;7(4):235-41.

18. Waljee AK, Joyce JC, Wren PA, Khan TM, Higgins PD. Patient reported symptoms during an ulcerative colitis flare: a Qualitative Focus Group Study. Eur J Gastroenterol Hepatol. 2009;21(5):558-64.

19. Farrell D, McCarthy G, Savage E. Self-reported symptom burden in individuals with inflammatory bowel disease. Journal of Crohn's and Colitis. 2016;315-22.

20. Van Assche G, Dignass A, Panes J, Beaugerie L, Karagiannis J, Allez M, et al. The second European evidence-based consensus on the diagnosis and management of Crohn's disease: definitions and diagnosis. J Crohns Colitis 2010;4(1):7-27.

21. Dignass A, Eliakim R, Magro F, Maaser C, Chowers Y, Geboes $\mathrm{K}$, et al. Second European evidence-based consensus on the diagnosis and management of ulcerative colitis part 1: definitions and diagnosis. J Crohns Colitis. 2012;6:965-90.

22. Bielefeldt K, Davis B, Binion DG. Pain and inflammatory bowel disease. Inflamm Bowel Dis. 2009;15:778-88.

23. Deberry JJ, Bielefeldt K, Davis BM, Szigethy EM, Hartman DJ, Coates MD. Abdominal pain and neurotrophic system in ulcerative colitis. Inflammatory Bowel Disease. 2014;20(12):2330-9.

24. Kalkan Ç, Soykan İ. Ülseratif kolit: Semptomlar, klinik bulgular ve doğal seyir. İçinde: Dağlı Ü, editör. İnflamatuvar Bağırsak Hastalığı. Ankara; Fersa Matbaacılık. 2014. s. 63-80.

25. Managing flares and other IBD symptoms. Crohn's and Colitis Foundation of America. http://www.crohnscolitisfoundation.org/assets/pdfs/Managingflares.pdfAvailable Date: 04 Nisan 2015.

26. Dignass AU, Gasche C, Bettenworth D, Birgegård G, Danese S, Gisbert JP, et al. European consensus on the diagnosis and management of iron deficiency and anaemia in inflammatory bowel diseases. J Crohns Colitis. 2015;211-22.

27. Gasche C1, Berstad A, Befrits R, Beglinger C, Dignass A, Erichsen $\mathrm{K}$, et al. Guidelines on the diagnosis and management of iron deficiency and anemia in inflammatory bowel diseases. Inflamm Bowel Dis. 2007;13(12):1545-53.

28. Özgürsoy Uran BN, Ünsal Avdal E, Tokem Y. Chapter 45 Approach to Inflammatory Bowel Disease With Current Guidelines. Adik Çamlı, Bilal Ak, Ramiz Arabacı, Recep Efe, editors. Recent Advances in Health Sciences. St. Kliment Ohridski University Press, Sofia, 2016.p: 472-87. ISBN 978-954-074136-9.

29. Shah SB, Hanauer SB. Treatment of diarrhea in patients with inflammatory bowel disease: concepts and cautions. Rev Gastroenterol Disord. 2007;7(Suppl 3):S3-10
30. Elkjaer M, Shuhaibar M, Burish J, Bailey Y, Scherfig H, Laugesen $B$, et al. E-health empowers patients with ulcerative colitis: A randomized controlled trial of the web-guided "constant-care” approach. Gut. 2010;59:1652-61.

31. O’Connor M, Bager P, Duncan J, Gaarenstrom. J. N-ECCO consensus statements on the European nursing roles in caring for patents with Crohn's disease or ulcerative colitis. J Crohns Colitis. 2013;7:744-64.

32. Greveson K, Woodward S. Exploring the role of the inflammatory bowel disease nurse specialist. British Journal of Nursing. 2013;22(17):16-22.

33. Bernstein KI, Promislow S, Carr R, Rawsthorne P, Walker JR, Bernstein CN. Information needs and preferences of recently diagnosed patients with inflammatory bowel disease. Inflamm Bowel Dis. 2011;17:590-8.

34. Savard J, Woodgate R. Young peoples' experience of living with ulcerative colitis and an ostomy. Gastroenterol Nurs 2009;32:33-41.

35. Oktay E. Beşinci Bölüm: İnflamatuar barsak hastalıkları: etyopatogenez. semptomatoloji. tanı ve komplikasyonlar. İçinde: Göksoy E, Uzunismail H, editörler. Gastrointestinal Sistem Hastalıkları. İ.Ü.Cerrahpaşa Tip Fakültesi Sürekli Tip Eğitimi Sempozyum Dizisi Yayın No: 23. 2001:199-206.

36. Peyrin-Biroulet L, Loftus EV Jr, Colombel JF, Sandborn WJ. Long-term complications. extraintestinal manifestations. and mortality in adult Crohn's disease in population-based cohorts. Inflamm Bowel Dis. 2011;17(1):471-8.

37. Bernstein N. Osteoporosis and other complications of inflammatory bowel disease. Current Opinion in Gastroenterology. 2002;18(4):428-34

38. Levine JS, Burakoff R. Extraintestinal manifestations of inflammatory bowel disease. Gastroenterol Hepatol. 2011;7(4):235-41.

39. Su CG, Judge TA, Lichtenstein GR. Extraintestinal manifestations of inflammatory bowel disease. Gastroenterology Clin North Am. 2002;31:307-27.

40. Römkens TEH, van Vugt-vun Pinxteren MWJ, Nagengast FM, van Oijen MGH, de Jong DJ. High prevalence of fatigue in inflammatory bowel disease: A case control study. J Crohns Colitis. 2011;5:332-7.

41. Jelsness-Jørgensen LP, Bernklev T, Moum B. Fatigue and disease-related worries among inflammatory bowel disease patients in remission; is it a reflection of coexisting IBS-like symptoms? A short report. J Psychosom Res. 2012;73(6):46972

42. Gisbert J, Gomollon FD. Common misconceptions in the diagnosis and management of anemia in inflammatory bowel disease. Am J Gastroenterol. 2008;103(5):1299-307.

43. Graff LA, Clara I, Walker JR, Lix L, Carr R, Miller N, et al. Changes in fatigue over 2 years are associated with activity of inflammatory bowel disease and psychological factors. Clin Gastroenterol Hepatol. 2013;11(9):1140-6.

44. Kemp K, Dibley L, Chauhan U, Greveson K, Jaghult S, Ashton $\mathrm{K}$, et al. Second N-ECCO Consensus Statements on the European Nursing Roles in Caring for Patients with Crohn's Disease or Ulcerative Colitis. J Crohns Colitis. 2018;760-76.

45. Ko JM, Gottlieb AB, Kerbleski JF. Induction and exacerbation of psoriasis with TNF-blockade therapy: a review and analysis of 127 cases. J Dermatol Treat. 2009;20:100 -8.

46. Rahier JF, Buche S, Peyrin-Biroulet L, Bouhnik Y, Duclos B, Louis E et al. Severe Skin Lesions Cause Patients With Inflammatory Bowel Disease to Discontinue Anti-Tumor Necrosis Factor Therapy. Clinical Gastroenterology and Hepatology. 2010;8(12):1048-55.

47. Herrlinger KR, Noftz MK, Dalhoff K, Ludwig D, Stange EF, Fellermann K. Alterations in pulmonary function in inflamma- 


\section{İBH ve Semptom Yönetimi}

tory bowel disease are frequent and persist during remission. Am J Gastroenterol. 2002;97:377-81.

48. Gondim FAAA, Brannagan TH, Wander HW, Chin RL, Latov N. Peripheral neuropathy in patients with inflammatory bowel disease. Brain. 2005;128:867-79.

49. Figueroa JJ, Loftus EV, Harmsen WS, Dyck PJB, Klein CJ. Peripheral neuropathy incidence in inflammatory bowel disease: A population Based Study. American Academy of Neurology. 2013;80:1693-7.

50. Vizzardi E, Sciatti E, Bonadei I, Bordonali T, Ricci C, Lanzarotto F, et al. Subclinical cardiac involvement in Crohn's disease and ulcerative colitis: an echocardiographic case-control study. Panminerva Medica. 2016;58(2):115-20.

51. Bunu DM, Timofte CE, Ciocoiu M, Floria M, Tarniceriu CC, Barboi OB, et al. Cardiovascular Manifestations of Inflammatory Bowel Disease: Pathogenesis, Diagnosis, and Preventive
Strategies. Gastroenterology Research and Practice, 2019, 3012509. doi:10.1155/2019/3012509.

52. Rungo C, Basit S, Ranthe MF, Wohlfahrt J, Langholz E, Jess T. Risk of ischaemic heart disease in patients with inflammatory bowel disease: A nationwide Danish cohort study. Gut. 2012;62(5):689-94.

53. Crohn's \& Colitis Foundation of America (CCFA). Information Resource Center. Managing Flares and Other IBD Symptoms. https://www.crohnscolitisfoundation.orgAvailableDate: August 2019

54. Karadağ F, Kalkan Oğuzhanoğlu N, Özdel O, Ergin Ş, Kaçar N. Psöriyazis hastalarında psikodrama: Stres ve stresle baş etme. Anadolu Psikiyatri Dergisi. 2010;11:220-22. 
